\title{
Carcinoma pancreas and fibrocalcific pancreatic diabetes: a dual association for weight loss
}

\author{
Kripa Elizabeth Cherian, Sahana Shetty, Nitin Kapoor, Thomas Vizhalil Paul
}

Department of Endocrinology, Christian Medical College, Vellore, Tamil Nadu, India

\section{Correspondence to} Professor Thomas Vizhalil Paul, thomasvpaul@yahoo.com

Accepted 8 March 2015

\section{(a) CrossMark}

To cite: Cherian $\mathrm{KE}$ Shetty S, Kapoor N, et al. BMJ Case Rep Published online: [please include Day Month Year] doi:10.1136/ bcr-2014-209058

\section{DESCRIPTION}

A 52-year-old man presented with upper abdominal pain and weight loss of $10 \mathrm{~kg}$ over 6 months. He had suffered from diabetes mellitus for the past 10 years and was on oral antidiabetic agents. He did not drink alcoholic. He had a history suggestive of steatorrhoea, which worsened following the intake of a fat-rich meal. On clinical examination, his body mass index was $20.5 \mathrm{~kg} / \mathrm{m}^{2}$ and there was no evidence of nutritional deficiencies. Abdominal examination was unremarkable. His biochemical evaluation was as follows-haemoglobin $12.7 \mathrm{~g} / \mathrm{dL}$ (normal range $(\mathrm{N})$ 13-18), glycated haemoglobin $10.5 \%(\mathrm{~N}<5.7)$, S.alkaline phosphatase $90 \mathrm{U} / \mathrm{L}$ (N 40-125), serum creatine: $0.9 \mathrm{mg} / \mathrm{dL}$ (N 0.6-1.2). An abdomen X-ray showed pancreatic calcification (figure 1). CT scan of the abdomen displayed the presence of a focal hypodense lesion, $4.4 \times 3.7 \times 3.3 \mathrm{~cm}$, in the head of the pancreas, with multiple instances of chunky ductal calcification (figure 2A). MRI of the abdomen showed a T2-hyperintense diffusion restricted, exophytic focal lesion in the head of the pancreas (figure 2B). The patient's blood level for tumour marker $\mathrm{Ca} 19.9$ was 924 (N 0-33). A diagnosis of fibrocalcific pancreatic diabetes (FCPD) with carcinoma of the head of the pancreas was performed. An endoscopic ultrasound guided biopsy from the mass confirmed the diagnosis. A multidisciplinary team discussion was held and treatment modalities including surgery were explained. The patient declined consent for Whipple procedure (pancreaticoduodenectomy) and hence was initiated on palliative chemotherapy with albumin bound paclitaxel (Abraxane) and gemcitabine.

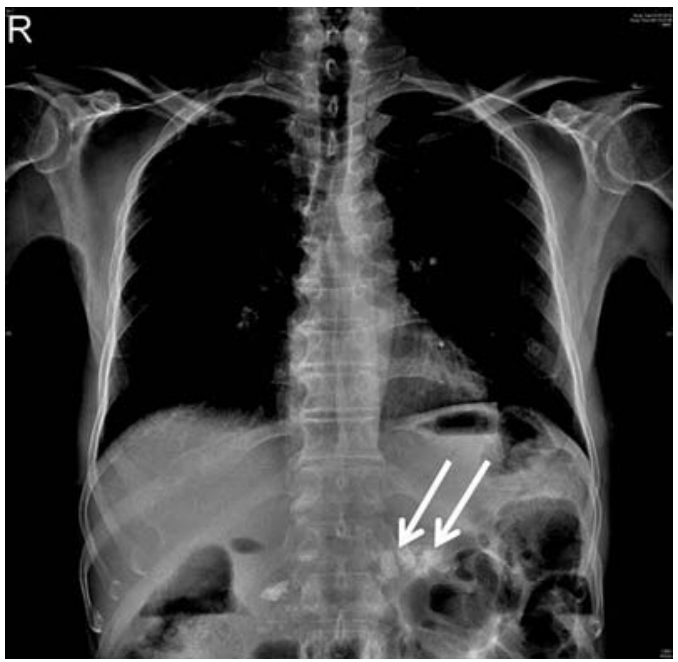

Figure 1 X-ray of the abdomen depicting large chunky calcification.
Tropical calcific pancreatitis (TCP) is a distinct variety of chronic pancreatitis, with a high prevalence being reported from southern India. The clinical presentation of TCP includes abdominal pain, steatorrhoea and weight loss, usually in early adulthood. The imaging classically shows multiple chunky calcifications in the pancreatic duct. Patients usually develop exocrine and endocrine dysfunction. When TCP progresses to diabetes, the condition is known as FCPD. Management of FCPD comprises of pancreatic enzyme supplementation and insulin therapy for diabetes. ${ }^{1}$ These patients are at a higher risk of developing pancreatic cancer (about 100-fold) as compared to those with other forms of pancreatitis. ${ }^{2}$ Anorexia with or without abdominal pain and progressive weight loss are typical features, so these patients need to be evaluated for occult pancreatic malignancy. The tumour marker CA19-9 is elevated in $70-80 \%$ of patients with pancreatic cancer and serial
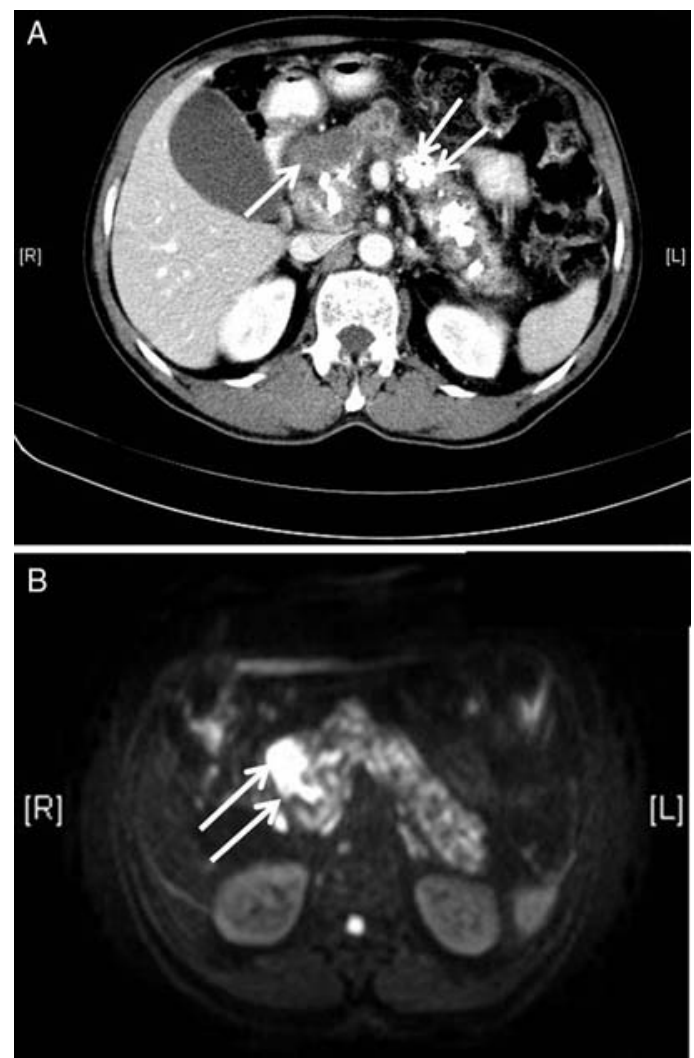

Figure 2 (A) CT scan of the abdomen displaying the presence of a focal hypodense lesion, $4.4 \times 3.7 \times 3.3 \mathrm{~cm}$, in the head of the pancreas, with multiple incidences of chunky ductal calcification. (B) MRI section showing T2-hyperintense diffusion restricted, exophytic focal lesion in the head of the pancreas. 
measurements during follow-up are useful to monitor for the development of malignancy. ${ }^{3}$

\section{Learning points}

- Tropical calcific pancreatitis is a rare cause of diabetes mellitus.

- The risk of developing pancreatic malignancy in this condition is almost 100-fold more than in those without the disease.

- Serial estimation of the tumour marker CA 19.9 serves in the identification of pancreatic malignancy at an earlier stage.
Acknowledgements The authors thank Banu Shankar for secretarial help.

Contributors KEC and SS wrote the manuscript. NK and TVP reviewed and revised the manuscript. KEC, SS, NK and TVP approved the final manuscript.

Competing interests None.

Patient consent Obtained.

Provenance and peer review Not commissioned; externally peer reviewed.

\section{REFERENCES}

1 Barman KK, Premalatha G, Mohan V. Tropical chronic pancreatitis. Postgrad Med J 2003;79:606-15

2 Chakraborty PP, Dutta D, Biswas K, et al. Pancreatic carcinoma in fibrocalcific pancreatic diabetes: an eastern India perspective. Indian J Endocrinol Metab 2012; 16(Suppl 2):S486-8.

3 Mohan V, Premalatha G, Pitchumoni CS. Tropical chronic pancreatitis: an update. J Clin Gastroenterol 2003;36:337-46.

Copyright 2015 BMJ Publishing Group. All rights reserved. For permission to reuse any of this content visit http://group.bmj.com/group/rights-licensing/permissions.

BMJ Case Report Fellows may re-use this article for personal use and teaching without any further permission.

Become a Fellow of BMJ Case Reports today and you can:

- Submit as many cases as you like

- Enjoy fast sympathetic peer review and rapid publication of accepted articles

- Access all the published articles

- Re-use any of the published material for personal use and teaching without further permission

For information on Institutional Fellowships contact consortiasales@bmjgroup.com

Visit casereports.bmj.com for more articles like this and to become a Fellow 